\title{
REVIEW
}

\section{Photoacclimation processes in phytoplankton: mechanisms, consequences, and applications}

\author{
Zvy Dubinsky*, Noga Stambler
}

The Mina \& Everard Goodman Faculty of Life Sciences, Bar-Ilan University, Ramat-Gan 52900, Israel

\begin{abstract}
In nature and in the laboratory, phytoplankton cells are exposed to fast and extreme fluctuations in light intensity. These include diel and seasonal changes in irradiance, and changes stemming from vertical mixing over the light field. In algal mass cultures and photobioreactors, similar changes take place as cultures grow denser and as cells are mixed rapidly in the system. To survive supraoptimal, free-radical-generating irradiance levels as well as prolonged exposure to dim light, phytoplankton species are capable of photoacclimation. Under low light, light-harvesting pigments such as phycobilins, chlorophylls, fucoxanthin and peridinin increase all the way to optically becoming black cells. The same pigments decrease under high light, resulting in cells being rather transparent. The opposite takes place with the photoprotective pigments $\beta$-carotene and astaxanthin and the elements of the xanthophyll cycle, all of which increase whenever cells are exposed to high irradiance levels, concomitant with enhanced activity of the antioxidant enzymes catalase, superoxydismutase, and peroxidase. These processes are complemented by up to 5-fold changes in RUBISCO per photosystem unit (PSU) levels, and parallel changes in light-saturated photosynthetic rates. Thus, light-harvesting and utilization efficiencies are maximized under low light, whereas photosynthetic carbon assimilation and throughput rates reach their peak values whenever light is sufficiently high. Maximal photosynthesis and growth rates have to be matched by correspondingly high respiration rates. Photoacclimation can be used to optimize biomass and target product yields in biotechnological applications.
\end{abstract}

KEY WORDS: Photoacclimation $\cdot$ Photoadaptation $\cdot$ Pigments $\cdot$ Xanthophyll cycle $\cdot$ Photosynthesis · Phytoplankton · Algae

\section{UNDERWATER LIGHT: TEMPORAL AND BATHYMETRIC VARIABILITY}

The importance of photoacclimation in aquatic phototrophs stems from the extreme temporal and spatial variability characteristic of the underwater light field. Terrestrial vegetation is also exposed to the cycles of light intensity resulting from the astronomic daily and annual changes in the relative positions of the Earth and Sun. However, in the aquatic environment these are amplified by the superimposed steep attenuation of light by water and the substances and particles dissolved and suspended in it (e.g. Smith \& Mobley 2008).
We illustrate this by 2 examples: the mesoeutrophic, monomictic Lake Kinneret (Israel), where due to the abundance of phytoplankton, and of humic substances, waters are greenish and turbid ( $1 \%$ of subsurface light penetration at 2 to $20 \mathrm{~m}$ ); and the transparent (1\% of subsurface light at 80 to $100 \mathrm{~m}$ ), blue-water Gulf of Aqaba (Eilat), Red Sea (Fig. 1). In Lake Kinneret, the most penetrating wavelength is $560 \mathrm{~nm}$, due to the combined absorption of phytoplankton and the blue light-absorbing dissolved organic carbon (DOC), or 'Gelbstoff'. In the Gulf of Eilat, and the Red Sea in general, as in all oligotrophic oceanic waters, the optical properties are dominated by those of the water 

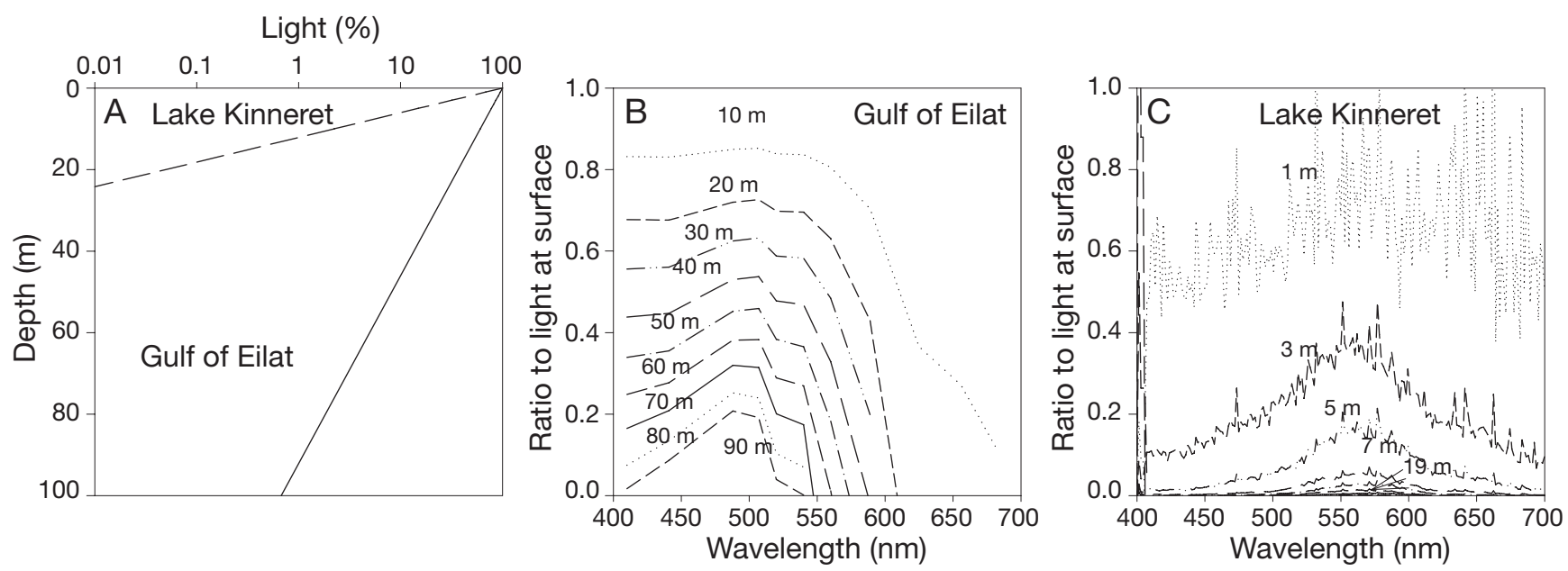

Fig. 1. (A) Light attenuation of photosynthetically active radiation (PAR) in (一) oligotrophic (blue) water (for example, the Gulf of Eilat, the vertical downwelling attenuation coefficient of underwater PAR $k_{\mathrm{d}(\mathrm{PAR})}=0.05 \mathrm{~m}^{-1}$ ) and in (- - -) eutrophic (green) water (for example, Lake Kinneret, Israel $k_{\mathrm{d}(\mathrm{PAR})}=0.38 \mathrm{~m}^{-1}$ ). (B) Change in spectral distribution of underwater light in the Gulf of Eilat from the surface to $90 \mathrm{~m}$ (10 m depth intervals). (C) Change in spectral distribution of underwater light in Lake Kinneret from the surface to $19 \mathrm{~m}$ ( $2 \mathrm{~m}$ depth intervals)

itself, rather than by the sparse phytoplankton and negligible DOC concentrations. Thus, any $10 \mathrm{~m}$ vertical transport of a phytoplankton cell results in a 2 orders of magnitude change in irradiance in Lake Kinneret, against only some $10 \%$ in the Gulf of Eilat. Not only are the phytoplankton assemblages affected by the underwater light field, its intensity and fluctuations, but conversely, the main determinants of the optical properties of all but the clearest, oligotrophic waters, are the myriads of minute phytoplankters and their pigments. This is not true of Case 2 waters of many coastal regions, and in many lakes and estuaries, where the optical properties are strongly influenced by chromophoric dissolved organic matter and/or suspended sediment. As phytoplankton populations wax and wane in response to seasonal fluctuations in light intensity, temperature, and most of all, nutrient availability, play a major role in determining characteristics of the underwater light field, and thereby, the light intensity to which they are exposed at any depth and time (Fig. 2, Dubinsky \& Berman 1979). We should point out that the depth of $1 \%$ of subsurface irradiance, $z_{1} \%$, differs from the euphotic depth, $z_{\text {eu }}$, which, is operationally thought of as the depth at which phytoplankton respiration equals gross photosynthesis, or, in physiological terms, the light compensation depth. For example, $z_{1} \%$ is the same on a cloudy and a clear day, while $z_{\text {eu }}$ would be much different and varies with latitude and the phytoplankton assemblages present (for a discussion see Banse 2004). We used $z_{1} \%$ to discuss optical properties of the light field per se, and $z_{\text {eu }}$ to discuss the effects of photoacclimation on the changing relations of photosynthesis and respiration.

The energy required for the vertical transport of cells depends on the wind force pushing on the water sur-

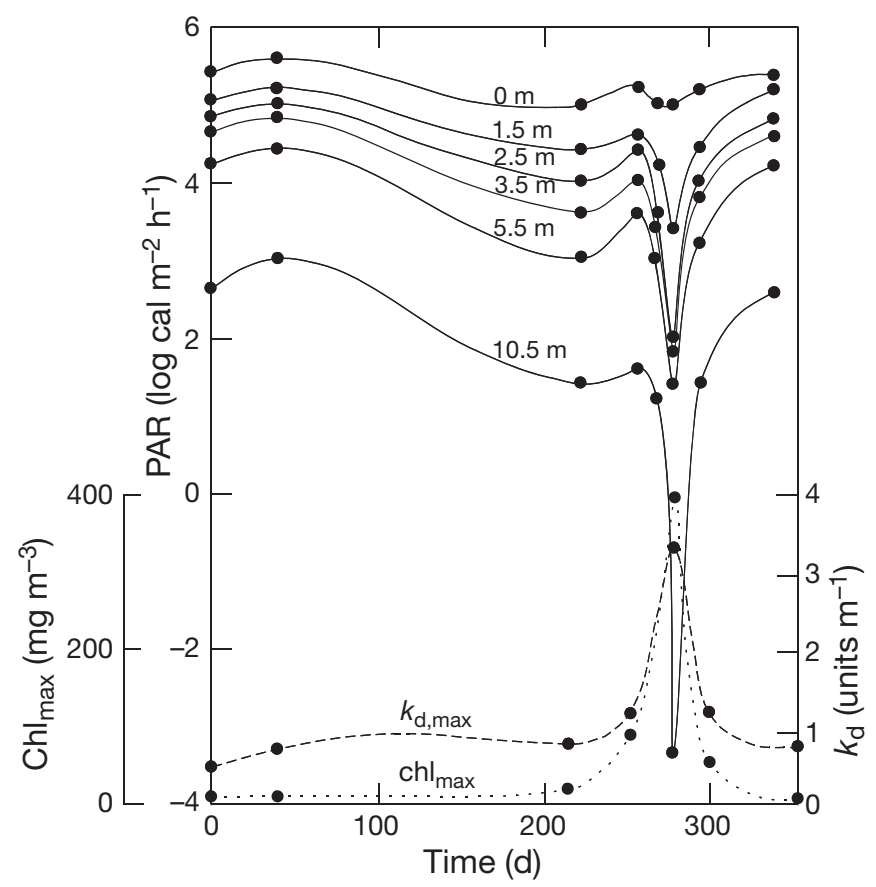

Fig. 2. Seasonal changes in bio-optical properties of Lake Kinneret from July 1973 until July 1974. Photsynthetically active radiation (PAR) (-), maximum chlorophyll concentration $\left(\mathrm{chl}_{\max }\right)(---)$ and maximal attenuation coefficient,

$\left(k_{\mathrm{d}, \max }\right)(\cdots)$. Data from Dubinsky \& Berman (1979)

face, relative to the stability of the water column. Furthermore, the more turbid a system is, the less kinetic energy is required to move phytoplankton through a given light gradient which occurs over a smaller depth interval. For example, in Lake Kinneret, diurnal winddriven oscillations of the metalimnion and the hours of daylight result in a situation in which the metalimnion in some parts of the lake is exposed to slightly higher 
light intensities than the other parts, causing higher concentrations of Chlorobium phaeobacteroides to develop (Rimmer et al. 2008). Energy needed for vertical cell transport is minimal under mixed conditions and is greatest in stable, stratified water bodies. Furthermore, the vertical mixing to which phytoplankton are commonly subjected at different frequencies and time scales may transport cells over orders of magnitude of irradiance levels over short time periods. Of course, swimming cells and those with gas vesicles actively position themselves at optimal irradiance levels (Cullen \& MacIntyre 1998). To be able to survive such changes in the ambient light field, phytoplankton have evolved diverse ways of optimizing their lightharvesting and utilization characteristics, allowing them to rapidly acclimate to new light environments. This ensures survival and growth even under very dim light, and also allows the cells to benefit from high light for accelerated growth, while avoiding photodynamic damage (see Stambler \& Dubinsky 2007, Dubinsky \& Schofield in press)

The present review focuses on photosynthesis, photoacclimation and photoadaptation of phytoplankton.

\section{PHYTOPLANKTON GROWTH AND RESPIRATION}

To allow for cell growth and multiplication and the resulting increase in population numbers during any given time interval gains in carbon assimilation must exceed respiratory losses. Thus, invariably, cell-doubling rates accelerate with light intensity within the species-specific range of irradiances allowing for growth (Fig. 3A). This relationship holds true even though respiratory losses increase with high-light driven accelerated biosynthesis of cellular building blocks (Fig. 3B,C).

\section{CELLULAR CHLOROPHYLL CONTENT}

The most visible photoacclimative change is the darkening of cells due to an increase in cellular pigment content, which is observed in all photosynthesizing cells grown under dim light (Fig. 3D,E; Falkowski et al. 1985, Dubinsky et al. 1986, Cunningham et al. 1989, Herzig \& Dubinsky 1992, 1993). In the case of Dunaliella, cells may increase their cellular chlorophyll
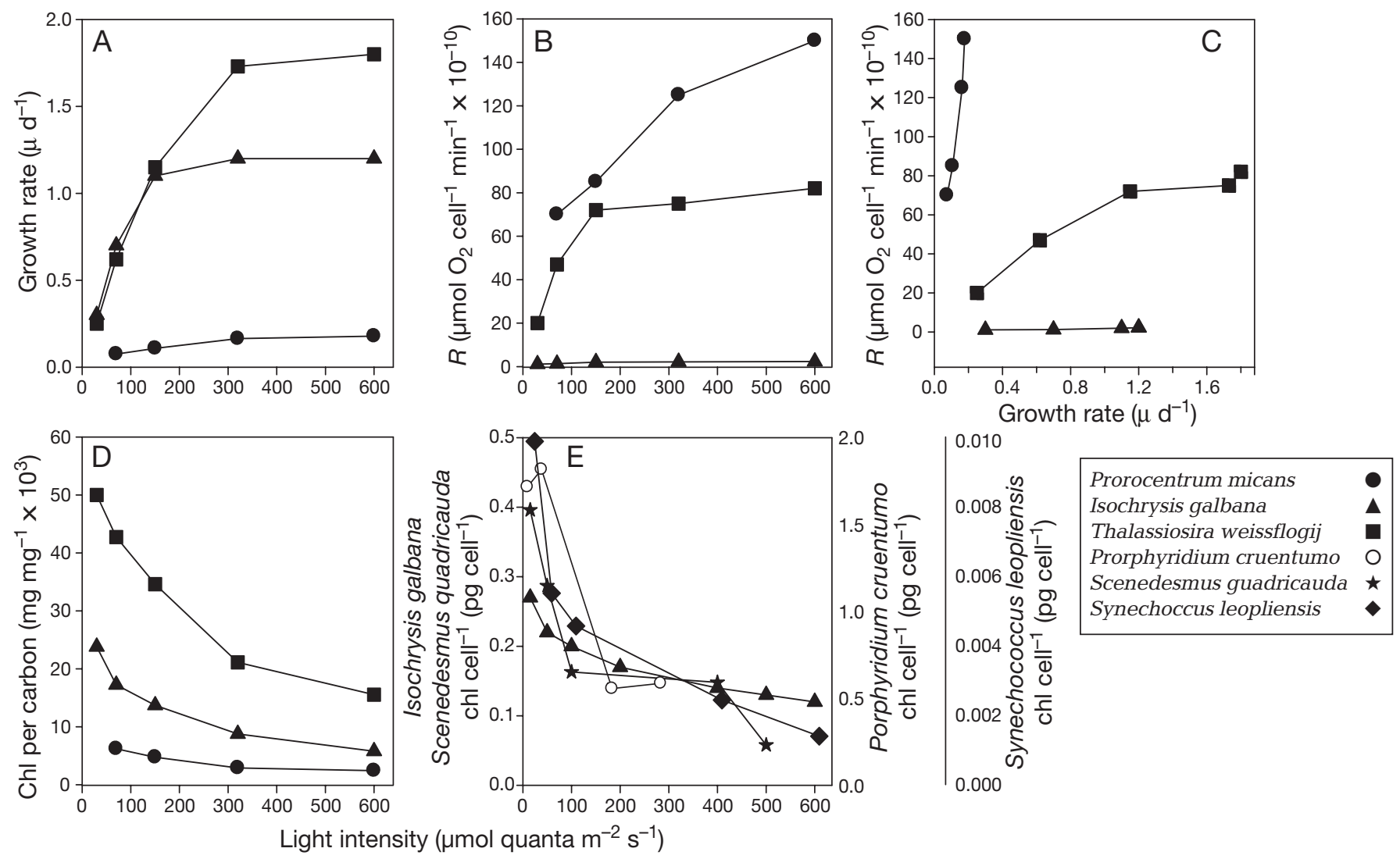

Light intensity $\left(\mu \mathrm{mol}\right.$ quanta $\left.\mathrm{m}^{-2} \mathrm{~s}^{-1}\right)$

Fig. 3. Response to light intensity of the phytoplankton algae. (A) Growth rate; (B) respiration rate $R_{i}$ (C) relationship between respiration and growth rate; (D) chlorophyll per carbon; and (E) chlorophyll per cell. Data from Falkowski et al. (1985), Dubinsky et al. (1986), Cunningham et al. (1989), Herzig \& Dubinsky $(1992,1993)$ 
content up to 12-fold when transferred from high to low light (Fig. 3D,E; MacIntyre et al. 2002). However, phytoplankton species differ in this respect (Johnsen \& Sakshaug 2007), and may be grouped into Chlorella versus Skeletonema types by the range of their change in chlorophyll content (Talling 1957). In any event, this strategy is doomed to be self-limiting since, as cellular pigmentation increases, so does the mutual shading of the incremental pigment molecules, leading to molecules in the 'depth' of the cell being in the shade of peripheral ones (Berner et al.1989). Due to the effects of self-shading, the light harvesting by cells is uncoupled from the increase in pigmentation. The absorption cross section per cell $\sigma \mathrm{B}$ is the product of cellular chlorophyll and $\mathrm{a}^{*}$. Under low light $\sigma \mathrm{B}$ increases less than the cellular chlorophyll content, due to the reduction in $\mathrm{a}^{*}$ caused by the stronger packaging effect. For instance, a 12-fold increase in chl cell ${ }^{-1}$, concomitant with a 7 -fold decrease in $\mathrm{a}^{*}$ would result in only a $12 / 7=1.7$ increase in $\sigma B$. (see Figs. $3 \& 7$ ). The decrease in $\mathrm{a}^{*}$ due to increased cell pigmentation is cell-size dependent, allowing the smallest cells to experience much reduced internal shading (Kirk 1986, Geider et al. 1986)

The course of the photoacclimative process from high to low light differs from the process that takes place in the opposite direction. When cells are exposed to an increase in irradiance, the dilution of cellular chlorophyll is facilitated by the concomitant acceleration in cell doubling. By contrast as cells encounter a reduction in light intensity, the increase in cellular pigmentation has to proceed at a rate fast enough to compensate for its dilution due to cell division. Therefore, acclimation to low light usually takes longer than to high light (Post et al. 1984, Prézelin et al. 1991). However, since the time for acclimation depends on how the acclimation parameter is defined, the converse of the above statement can also appear to be true (Cullen \& Lewis 1988).

\section{PHYCOBILINS}

In cyanobacteria, the main light-harvesting antenna pigments are 2 phycobilins (blue [wavelengths maximum peak, $\lambda_{\text {max }} \approx 553$ to $615 \mathrm{~nm}$ ] phycocyanin and red $\left[\lambda_{\text {max }} \approx 520\right.$ to $570 \mathrm{~nm}$ ] phycoerythrin), rather than chlorophyll, which mainly functions in the reaction centers (e.g. Falkowski \& Raven 2007). These pigments are incorporated into specific structures, the phycobilisomes; their size and optical cross section increases under low light, while their ratios are affected by the spectral composition of the light field (Falkowski \& La Roche 1991), with an increase in the blue component favoring the predominance of phycoerythrin. How- ever, there are some species of cyanobacteria such as Planktothrix rubescens that are unable to change the phycobilin ratio (Kromkamp et al. 2001, Walsby et al. 2001, Oberhaus et al. 2007). The unicellular red alga Porphyridium cruentum has been the focus of much applied research due to its profuse production of commercially valuable phycocolloids (Dufosse et al. 2005). Among the many aspects of the biology of P. cruentum, its photoacclimation capability has been reported. The ellipsoidal phycobilisomes of $P$. cruentum has been found to readily change in response to ambient light (Arteni et al. 2008).

\section{PHOTOACCLIMATION, CHROMATIC ADAPTATION/ACCLIMATION}

In the pre-2000 literature the term 'chromatic adaptation' was used indiscriminately for both genetically controlled and phenotypic responses to the light spectrum (for details see below, this section, and Table 1). The common usage in the theoretical literature is to separate light intensity effects from changes driven by differences in spectral distribution. It is important to state clearly that photoacclimation is a process by which phototrophs regulate the amount of pigment and other components of the photosynthetic machinery in response to light intensity, whereas 'chromatic acclimation' is a mechanism by which the light harvesting is optimized to differences in the spectral composition of underwater light. However, in most field and laboratory work chromatic adaptation and acclimation are frequently combined. In the laboratory, virtually all photoacclimation studies reduce irradiance levels, carefully avoiding changes in spectral distribution, attenuating light by neutral filters (not by voltage changes in the light source, which would also affect spectral distribution). In the field, separation of intensity changes from spectral shifts is difficult, as phytoplankton are exposed to a combined, depth-dependent reduction in potosynthetically active radiation (PAR), and a concomitant narrowing of the spectrum towards a window in the green or blue domains, depending on the trophic state of the water body being investigated (Jerlov 1976). The issue of 'chromatic adaptation' has been the source of considerable controversy, and many have claimed that it only reflects the response to differences in the intensity of absorbed light (Bidigare et al. 1990, Falkowski \& La Roche 1991, Talarico \& Maranzana 2000). This is in accordance with Dring (1981, p. 271), who summarized that: 'The changes in pigment composition that are observed with increasing depth in marine algae are largely adaptations to low irradiance, and not to the spectral composition of underwater light'. 
Table 1. Definitions, symbols and abbreviations commonly used relation to photoacclimation

\begin{tabular}{|c|c|c|}
\hline Abbreviation & Parameters & Units commonly used \\
\hline$a^{*}$ & $\begin{array}{l}\text { In vivo, spectral-averaged chlorophyll-specific } \\
\text { absorption cross section }\end{array}$ & $\mathrm{m}^{2} \mathrm{mg}^{-1} \mathrm{chl} a$ \\
\hline $\mathrm{Chl} \mathrm{a}$ & Chlorophyll concentration & e.g. pg chl cell ${ }^{-1} ; \mathrm{mg} \mathrm{chl} \mathrm{m}{ }^{-3}$ \\
\hline$E_{\mathrm{C} \prime}$ & Compensation light intensity & $\mu \mathrm{mol}$ quanta $\mathrm{m}^{-2} \mathrm{~s}^{-1}$ \\
\hline$E_{k \prime}$ & $\begin{array}{l}\text { Light intensity at incipient saturation of } \\
\text { photosynthesis }\end{array}$ & $\mu \mathrm{mol}$ quanta $\mathrm{m}^{-2} \mathrm{~s}^{-1}$ \\
\hline$I_{\mathrm{g}}$ & Growth irradiance & $\mu \mathrm{mol}$ quanta $\mathrm{m}^{-2} \mathrm{~s}^{-1}$ \\
\hline $\begin{array}{l}P \text { vs. } E \text { curve } \\
\text { Formerly } P \text { vs. } I\end{array}$ & $\begin{array}{l}\text { Relationship between photosynthesis rate and } \\
\text { light intensity. Represented as a curve }\end{array}$ & \\
\hline$P_{\mathrm{G}}$ & Gross photosynthesis rate & $\begin{array}{l}\left(\mathrm{O}_{2} \text { evolved or } \mathrm{CO}_{2} \text { assimilated }\right) \\
(\text { cell or chl })^{-1} \text { time }^{-1}\end{array}$ \\
\hline$P_{\max }$ & Light saturated rate of photosynthesis & $\begin{array}{l}\left(\mathrm{O}_{2} \text { evolved or } \mathrm{CO}_{2} \text { assimilated }\right) \\
(\text { chl or cell })^{-1} \text { time }^{-1}\end{array}$ \\
\hline$P_{\mathrm{N}}$ & Net photosynthesis & $\begin{array}{l}\left(\mathrm{O}_{2} \text { evolved or } \mathrm{CO}_{2} \text { assimilated }\right) \\
(\text { cell or pg chl })^{-1} \text { time }^{-1}\end{array}$ \\
\hline PSU number & Number of photosynthetic units & PSU cell ${ }^{-1}$ \\
\hline PSU size & Photosynthetic unit size & $\begin{array}{l}\text { mol chl a mol-1 } \mathrm{O}_{2} \text { evolved per } \\
\text { single turnover flash }\end{array}$ \\
\hline$R$ & Dark respiration & $\begin{array}{l}\left(\mathrm{O}_{2} \text { consumed or } \mathrm{CO}_{2} \text { evolved }\right) \\
(\text { cell or pg chl })^{-1} \text { time }^{-1}\end{array}$ \\
\hline$z_{1} \%$ & Depth at which subsurface light is reduced to $1 \%$ & 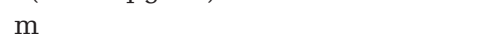 \\
\hline$z_{\mathrm{eu}}$ & $\begin{array}{l}\text { Euphotic depth, where gross photosynthesis }\left(P_{\mathrm{G}}\right) \text { equals } \\
\text { phytoplankton respiration (the light compensation depth) }\end{array}$ & $\mathrm{m}$ \\
\hline$z_{\text {mix }}$ & Mixing depth from the surface to the thermocline & $\mathrm{m}$ \\
\hline$\alpha$ & $\begin{array}{l}\text { Initial slope of the } P \text { vs. } E \text { curve in the light- } \\
\text { limited region }\end{array}$ & $\begin{array}{l}\left(\mathrm{O}_{2} \text { evolved or } \mathrm{CO}_{2} \text { assimilated }\right) \\
\quad(\text { cell or } \mathrm{chl})^{-1}\left(\mu \mathrm{mol} \text { quanta } \mathrm{m}^{-2} \mathrm{~s}^{-1}\right)^{-1}\end{array}$ \\
\hline$\phi$ & $\begin{array}{l}\text { Quantum yield, the ratio of moles } \mathrm{O}_{2} \text { evolved } \\
\text { (or } \mathrm{CO}_{2} \text { assimilated) } \mathrm{mol}^{-1} \text { photons absorbed }\end{array}$ & Dimentionless \\
\hline$\mu$ & Specific growth rate & time $^{-1}$, (usually d $\mathrm{d}^{-1}$ ) \\
\hline$\sigma_{\mathrm{PSU}}$ & In vivo absorption cross section of the entire PSU & Usually $\AA$ \\
\hline$\tau$ & Turnover time of PSU at $P_{\max }$ & $\mathrm{ms}$ \\
\hline Photoacclimation & $\begin{array}{l}\text { Short-term acclimation of a photosynthetic organism } \\
\text { to its changing irradiance. This acclimation is within the } \\
\text { limits of its genetic potential and environmental } \\
\text { constraints, within the life span of individuals }\end{array}$ & \\
\hline Photoadaptation & $\begin{array}{l}\text { Long-term evolutionary adaptation of photosynthetic } \\
\text { organisms to ambient irradiance, through selection of } \\
\text { genetically determined phenotypes }\end{array}$ & \\
\hline
\end{tabular}

In contrast, chromatic adaptation in the strict sense has been conclusively documented as a phenomenon separate from photoacclimation only in cyanobacteria. The most dramatic and easily visible consequence of chromatic acclimation is the change in the ratio of phycocyanin (PC) to phycoerythrin (PE). The basic structure of the phycobilisomes in the cyanobacterium Fremyella diplosiphon, and their response to red and blue light is illustrated in Fig. 4. The phycobilisome consists of 6 rods radiating from the core, which shorten under high light and elongate under low light. The ratios of the 3 major types of phycobiliproteins: phycoerythrin, $\operatorname{PE}\left(\lambda_{\max }=565 \mathrm{~nm}\right)$, phycocyanin, $\mathrm{PC}\left(\lambda_{\max }=620 \mathrm{~nm}\right)$, and allophycocyanin (AP) $\left(\lambda_{\max }=650 \mathrm{~nm}\right.$ ) (Kehoe \& Gutu 2006) change in the case of chromatic acclimation to different spectral conditions.
Marine Synechococcus strains differ in their ability for chromatic acclimation, depending upon their previous adaptation to light spectra. Thus, one strain, but not the other, increases its phycourobilin/phycoerythrobilin chromophore ratio when growing in blue light.

This ability to chromatically adapt may explain the predominance of Synechococcus strains in the water column of the oceans (Palenik 2001).

The oxyphotobacterium Acaryochloris marina photoacclimates to different light intensities and spectra by changing photosynthetic pigment ratios. In this organism the main photosynthetic pigment is chl $d$, with an in vivo absorption peak at 708 to $720 \mathrm{~nm}$, while chl $a$ is considered an accessory pigment. The cellular content of chl $d$, increased in cultures grown under low irradiance and red or green light compared to 


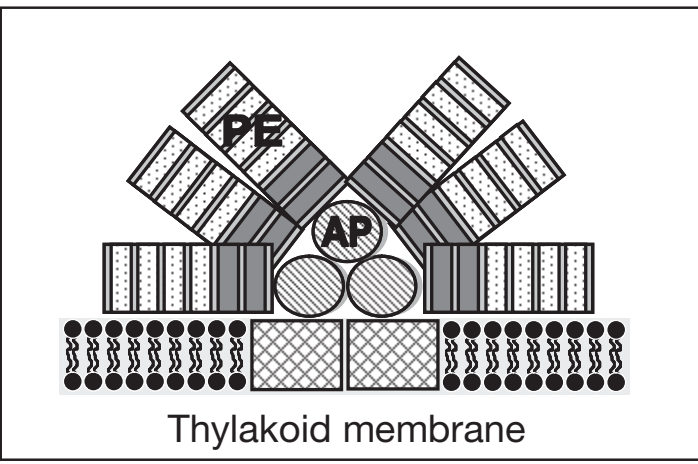

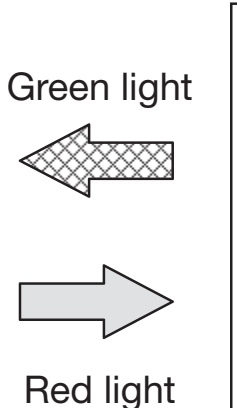

Red light

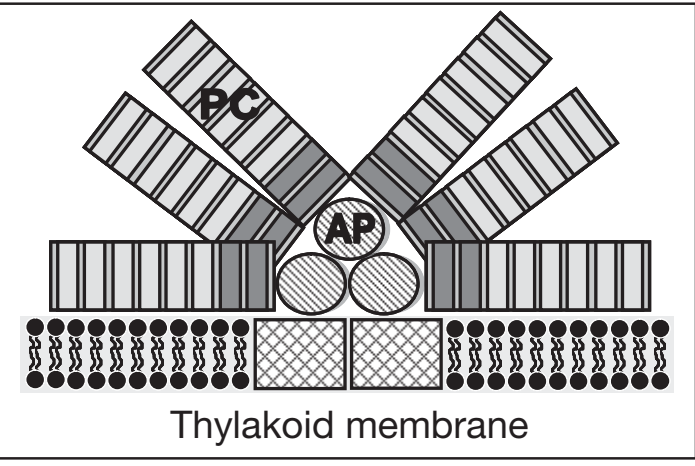

Thylakoid membrane

Fig. 4. Red and green light-induced structural changes in a Fremyella diplosiphon phycobilisome (PBS). The PBS structural unit is a hexamer allophycocyanin (AP) in the core, and phycocyanin (PC), and/or phycoerythrin (PE) in the rods. Based on Kehoe \& Gutu (2006)

those grown under intense white light. Under both low irradiance and low intensity non-white light sources, chl $a /$ chl $d$, phycocyanin/chl $d$ and carotenoid/chl $d$ ratios were all lower than when grown under bright, white light. (Gloag et al. 2007).

Seaweed taxa differing in pigment array tend to monopolize habitats where their specific spectral absorption properties are advantageous, given the distribution of underwater light. A common feature of seaweed zonation is the gradual disappearance of chlorophytes along with that of the red spectral component, while red algae take over as the light narrows around the blue region (Lobban \& Harrison 1996).

\section{ULTRASTRUCTURE}

The photoacclimation process, which involves massive changes in cellular content of both light-harvesting and photoprotective pigments, is also reflected in major adjustments in the ultrastructure of phytoplankton. Under low light, there is always an increase in the number of thylakoids per granum (Berner et al. 1989, Fisher et al. 1998), resulting from an increase in the total area of these membranes required to accommodate the added pigment molecules (Fig. 5). In Cyanobacteria, the phycobilisomes are arranged on thylakoids that do not stack as grana, and there are no chloroplasts, whereas in the prochlorophytes, thylakoids are paired and stacked, forming grana. The lightharvesting pigments are anchored on the thylakoid membranes, while the photoprotective $\beta$-carotene and astaxanthin are concentrated in globules. The thylakoid membranes are remarkably fluid, with their dynamic change in stacking and area upon transfer from high to low light and vice versa being completed within $24 \mathrm{~h}$ (Berner et al. 1989). Phaeocystis antarctica shows an increase in thylakoid stacking in response to low light and a decrease in potential light-scattering cellular organelles, due to their rearrangement. These may include pyrenoids, the Golgi apparatus, and vesicles (Moisan et al. 2006).

\section{PIGMENT RATIOS}

In addition to the changes in cellular chlorophyll and phycobilin content that are negatively correlated with irradiance outlined in the previous section, most other plant pigments also respond to ambient irradiance (Figs. 3D-E \& 6, MacIntyre et al. 2002). In general, all light-harvesting pigments increase under dim light. These include the carotenoids fucoxanthin and peridinin, in addition to all chlorophylls, phycoerythrin, and phycocyanin. These 2 orange-colored carotenoids

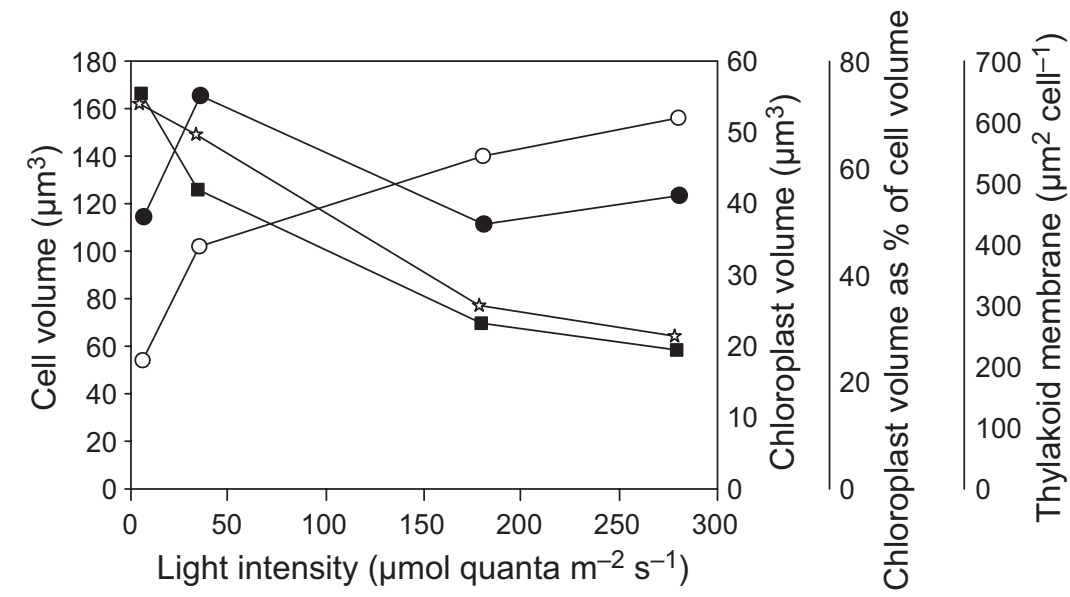

Fig. 5. Porphyridium cruentum. Cell volume (O), chloroplast volume (•),

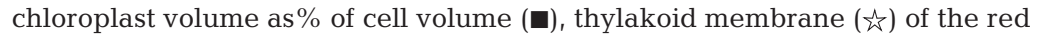
algae, as a function of light intensity. Data from Cunningham et al. (1989) 


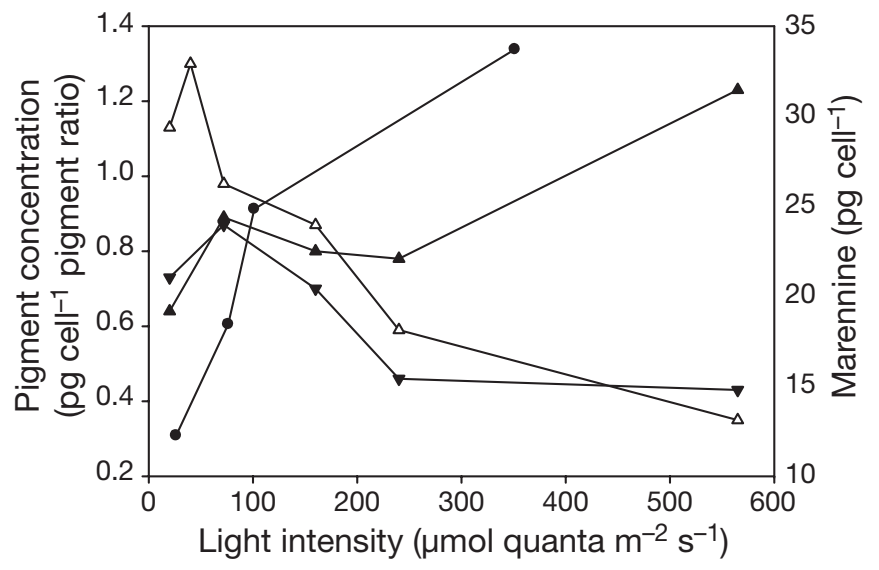

Fig. 6. Pigment concentrations, phycocyanine per cell $(\boldsymbol{\nabla})$, phycocyanine per chlorophyll $(\mathbf{\Delta})$ and chlorophyll per cell $(\Delta)$ in the cyanobacterium Microcystis aeruginosa as a function of growth light intensity. Data from Raps et al. (1983). Marennine contents in the diatom Haslea ostrearia $(\bullet)$. Data from Rech et al. (2008)

harvest wavelengths such as green light that are poorly absorbed by chlorophylls, and efficiently transfer excitation energy to the chlorophyll molecules in reaction centers. Other carotenoids such as $\beta$-carotene and astaxanthine show the opposite relation to irradiance, since they function as photoprotective light filters (Krinsky 1989, Fan et al. 1995, Choudhury \& Behera 2001, Wang et al. 2003, Schagerl \& Muller 2006), with concentrations increasing under high light. These carotenoids act by quenching free radicals, and converting excess light energy into heat. Striking examples are the 'blood' algae Haematococcus pluvialis, (Zlotnik et al. 1993) and Chlamydomonas nivalis, the cause of the spectacular red 'watermelon' snow (Bidigare et al. 1993). The commercial production of $\beta$ carotene and astaxanthine is based on the exposure of cultures to high light (Boussiba et al. 1999, Boussiba \& Vonshak 2000).

Light-harvesting and photoprotective carotenoids follow opposite courses in relation to photoacclimation. Therefore, it is important not to try to correlate total carotenoid content and photoacclimation, since the changes in the 2 groups tend to cancel out each other (Figs. 3 \& 6).

A special aspect of coping with excess light by phototrophs is that of the xanthophyll-cycle pigments, which increase thermal energy dissipation as lightharvesting rates exceed those by which absorbed energy can be used in photochemistry. In chlorophytes and higher plants, the cycle consists of the interchangeable xanthophylls zeaxanthin (Z), violaxanthin $(\mathrm{V})$, and antheraxanthin (A), while in other algal taxa, that role is fulfilled by diadinoxanthin (DD) and diatoxanthin (DT) (e.g. Demers et al. 1991, Anwaruzzaman et al. 2004, Latowski et al. 2004). Under high light, the cell content of the xanthophyll-cycle elements increases, and under low-to-highlight transition, an epoxidation converts DD and DT, shunting potentially harmful energy towards thermal dissipation. Some taxa such as Cyanophyta, Cryptophyta, and most Rhodophyta, probably lack the xanthophyll cycle and resort to alternative highlight protection strategies (Latowski et al. 2004). For the relation of the xanthophyll cycle to energy dissipation and non-photochemical quenching (NPQ), see 'Thermal energy dissipation, NPQ and the xanthophyll cycle'.

Changes in pigment ratios and cellular concentrations in response to different light intensities have been observed in several Cyanobacteria and probably exist in others (MacIntyre et al. 2002). In the filamentous marine cyanobacterium Trichodesmium, phycoerythrobilin was reversibly converted to phycourobilin when grown under high irradiance. This toggle can be seen as an alternative to the 'classic' xanthophyll cycle since phycourobilin dissipates excess energy as fluorescence (Subramaniam et al. 1999). Under high irradiance, Anabaena torulosa synthesized increased amounts of carotenoids, and Nostoc sp. increased zeaxanthin and myxoxanthophyll. Anabaenopsis elenkinii produced high amounts of myxoxanthophyll and $\beta$ carotene. Interestingly, Anabaena cylindrica hardly showed any variation in carotenoid content under different irradiances (Schagerl \& Muller 2006).

Under low light ( $25 \mu \mathrm{mol}$ quanta $\mathrm{m}^{-2} \mathrm{~s}^{-1}$ ) the marine diatom Haslea ostrearia synthesizes and accumulates a blue pigment known as 'marennine' while under saturating light (350 $\mu \mathrm{mol}$ quanta $\left.\mathrm{m}^{-2} \mathrm{~s}^{-1}\right)$, its quantity is reduced and the cells are green (see Rech et al. 2008, Fig. 6).

Due to the diverse roles of photosynthetic pigments, changes in their cellular contents associated with photoacclimation usually also result in major changes in pigment ratios. For instance, as the chlorophyte Haematococcus acclimates to high light, astaxanthin increases coloring cells bright red, while chlorophyll decreases to nearly undetectable levels. The converse takes place when this organism is cultured in dim light: astaxanthin disappears and cells turn green (Zlotnik et al. 1993).

\section{FREE RADICAL QUENCHERS AND ANTIOXIDANT (AO) ENZYMES}

Since the site of oxygen evolution by PSII is in close proximity to cellular structures sensitive to free-radical damage within and outside the photosynthetic apparatus, mechanisms have evolved in all plants to minimize such damage. These are especially pronounced under intense insolation, and include, besides the pigment- 
based systems discussed in the previous section, the antioxidant enzymes, catalase, super-oxy-dismutase, and ascorbate peroxidase (Wolfe-Simon et al. 2005). These enzymes respond rapidly to irradiance level even on a diel cycle, increasing with light and waning at sunset (Levy et al. 2006).

\section{PHOTOSYNTHETIC UNIT (PSU) SIZE, $\sigma_{\mathrm{PSU}}$}

As described in the ' $Z$ scheme', the photosynthetic apparatus is organized in discrete PSUs, which contain the 2 photosystems (PS), I and II, all their components and respective and shared antenna pigments. The organization of the light-harvesting antennae of the PSU adjusts in the course of photoacclimation in 2 different ways: change in antenna size and/or change in PSU number (Fig. 7A,B). In some algal species and in higher plants, photoacclimation is accomplished by changing the total number of PSUs in the cell while the number of pigment molecules in each antenna remains constant. The opposite is the case in most phytoplankton taxa, where, upon exposure to reduced irradiance, antenna size grows in direct proportion to the increase in cellular chlorophyll (for a review see Prézelin 1981). Two strains of Emiliania huxleyi (Haptophyta) B11 and B92 displayed markedly different photoacclimative responses of PSU number, and in reaction center complexes of the PSII and PSI (RCII, $\mathrm{RCI}), \mathrm{RCII}$ cell $^{-1}$ and RCI cell ${ }^{-1}$, with growth irradiance, even though both showed a similar increase in cellular chlorophyll. Emiliania huxleyi B11 displayed a significant decrease in RCII cell ${ }^{-1}$ (31\%) but not in RCI cell ${ }^{-1}$ with increasing light intensity. In contrast, Emiliania huxleyi B92 showed a significant increase in both RCII cell-1 $(21 \%)$ and RCI cell ${ }^{? 1}$ (50\%) from the lowest to the highest growth irradiance. (Suggett et al. 2007). The in-vivo absorption cross section of the entire PSU, $\sigma_{\mathrm{PSU}}$, is derived as the product of $\mathrm{a}^{*}$ and the PSU size. PSU size is the number of chlorophylls associated with each PSU, sensu Emerson \& Arnold (1932). Since, both PSU size and $\mathrm{a}^{*}$ change in the course of photoacclimation, so does $\sigma_{\mathrm{PSU}}$ (Fig. 7E). The different photoacclimative strategies do not necessarily reflect in the photosynthesis versus irradiance $(P$ vs. E) relationships, since the initial slope is a function of the product of absorptivity and of photosynthetic efficiency, whereas, $P_{\max }$ in terms of per cell, depends on the amount of RUBISCO per PSU (Fisher et al. 1989). However, in general, higher PSU-numbers should increase $P_{\max }$, whereas changes in PSU size primarily affect $\alpha$. These relationships are not universally seen, since increasing PSU numbers occurs under low light while rising RUBISCO takes place when cells are exposed to high irradiance, and both result in higher $P_{\max }$ rates.
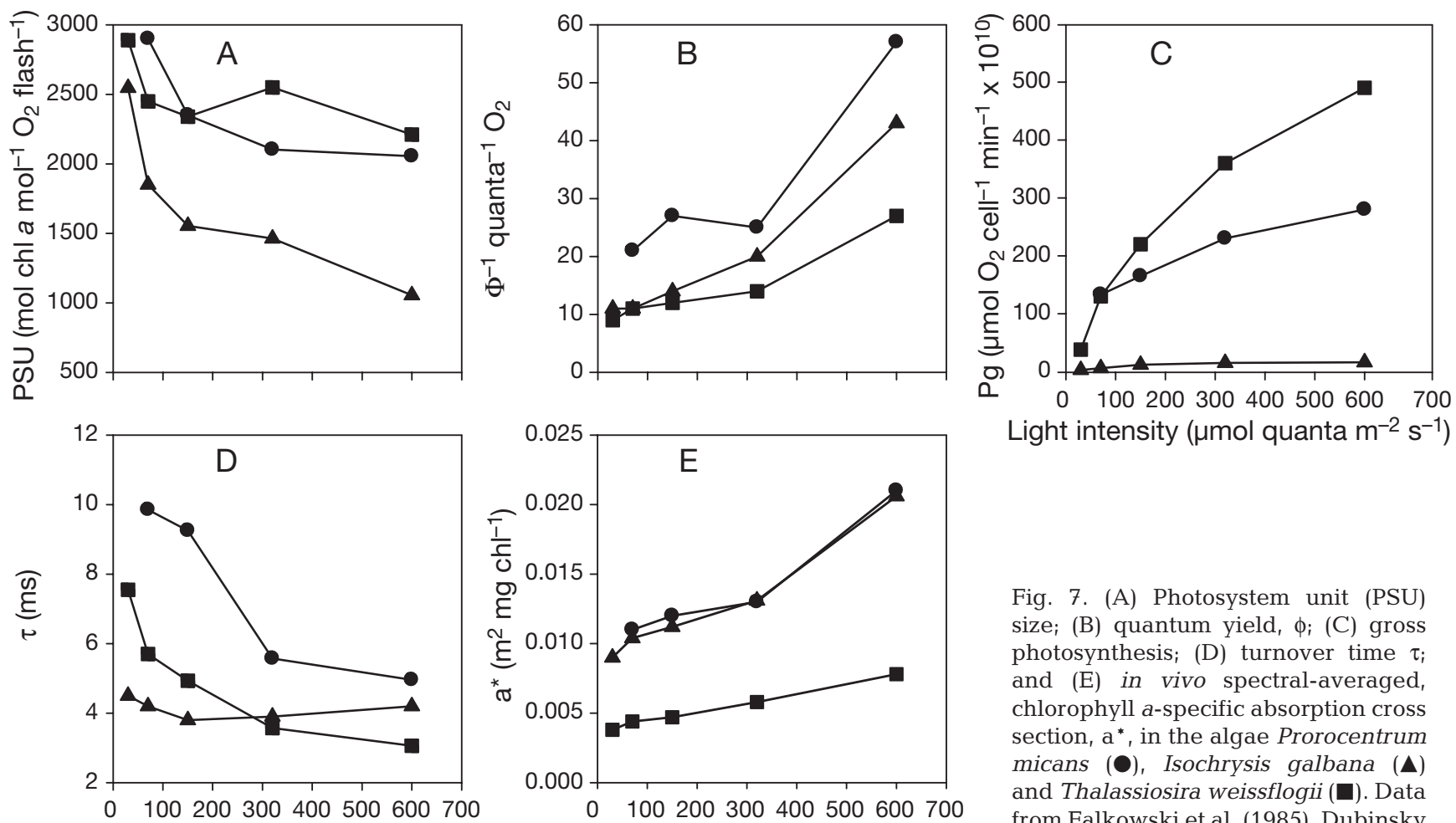

Light intensity ( $\mu \mathrm{mol}$ quanta $\mathrm{m}^{-2} \mathrm{~s}^{-1}$ )

Fig. 7. (A) Photosystem unit (PSU) size; (B) quantum yield, $\phi_{i}$ (C) gross photosynthesis; (D) turnover time $\tau_{\text {; }}$ and (E) in vivo spectral-averaged, chlorophyll a-specific absorption cross section, $\mathrm{a}^{*}$, in the algae Prorocentrum

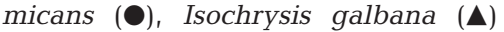
and Thalassiosira weissflogii ( $\mathbf{\square})$. Data from Falkowski et al. (1985), Dubinsky

Light intensity ( $\mu \mathrm{mol}$ quanta $\mathrm{m}^{-2} \mathrm{~s}^{-1}$ ) et al. (1986) 


\section{PHOTOSYNTHESIS VERSUS IRRADIANCE (P VS. E) RELATIONSHIP}

All the parameters of the $P$ vs $E$ relationship change in the course of photoacclimation. Dark respiration, discussed here, affects $E_{\mathrm{c}}$ the light compensation irradiance level. Therefore, under low light, respiration rates are low, leading cells to reach compensation level at considerably lower irradiances than those required by rapidly respiring, fast-growing, highlight-acclimated cells. Naturally, dark respiration $(R)$ is the difference between net $\left(P_{\mathrm{N}}\right)$ and gross photosynthesis $\left(P_{\mathrm{G}}\right)$, Eq. (1), thereby determining the amount of residual photosynthate available, to provide the carbon skeletons required as building blocks for new cells.

$$
P_{\mathrm{N}}=P_{\mathrm{G}}-R
$$

To allow for growth in natural phytoplankton assemblages and in algal cultures grown under a photoperiod, daytime gross photosynthesis gains must exceed the diel integral of dark respiration. The initial slope of the $P$ vs. $E$ curve, $\alpha$, when calculated on a per cell or biomass basis, increases under low light corresponding to improved light utilization efficiency. However, that slope is the product of the quantum yield $\phi$, and of $\mathrm{a}^{*}$, the in vivo chlorophyll-specific absorption cross section (Eq. 2), and for the maximal quantum yield, in the linear, light-limited region of the $P$ vs. $E$ relationship:

$$
\alpha=\phi \mathrm{a}^{*}
$$

These parameters differ in their response to low light photoacclimation; the quantum yield increases, while $\mathrm{a}^{*}$ is reduced as documented in several studies both in nature (Dubinsky \& Berman 1976, 1981, Dubinsky et al. $1984 \mathrm{a}, \mathrm{b}$ ) and in the laboratory (Dubinsky et al. 1986). Thus, the photoacclimative change in $\alpha$ may be small, and the prediction of the effect of the process on the initial slope of the $P$ vs. E relationship is variable. The in vivo spectral average optical absorption crosssection of chl a is currently symbolized by $\mathrm{a}^{*}$. For discussion of $\mathrm{a}^{*}$, symbols, definitions and equations see Schanz et al. (1997). This parameter underscores the difference in optical properties between the usually measured, extracted chlorophyll, and when incorporated in live cells. Furthermore, the spectrophotometric determination of chlorophyll is based on a couple of carefully chosen wavelengths (Jeffrey \& Humphrey 1975), whereas $\mathrm{a}^{*}$ is averaged over the entire visible spectrum, and is defined in area units, not as concentration. Counter intuitively, $\mathrm{a}^{*}$ decreases upon lowlight photoacclimation due to increased intermolecular shading or the overlap among the cross sections of pigment molecules (Kirk 1986, Berner et al. 1989, Johnsen \& Sakshaug 2007, Marra et al. 2007). The reported values of $\mathrm{a}^{*}$ range between 0.0038 (in large lowlightacclimated cells) and $0.02 \mathrm{~m}^{2} \mathrm{mg} \mathrm{chl}^{-1}$ (in tiny, highlight cells, Schanz et al. 1997). That effect is more pronounced in large cells, as the path length within cells is large. In summary, the decrease in $\mathrm{a}^{*}$ with increasing cellular pigmentation is a self-limiting strategy, and only in a few cases do we find low/high light-acclimated cellular chlorophyll contents ratios >12 (Z. Dubinsky unpubl. data).

The quantum yield $\phi$ of photosynthesis is defined as the ratio of moles $\mathrm{O}_{2}$ evolved (or $\mathrm{CO}_{2}$ assimilated) per mole photons absorbed (for definitions and discussion see Dubinsky 1980). The quantum yield may easily increase by 2 orders of magnitude between its low value under saturating light and its stoichiometrically set maximal boundary of $1 / 8$, or 1 mol oxygen evolved for 8 photons absorbed (Fig $7 \mathrm{C}$ ). This value is rarely seen as whenever the nitrogen source is nitrate rather than ammonia, at least 2 more photons are consumed in its reduction. Nevertheless, in lowlight-acclimated colonies of the Red Sea coral Stylophora pistillata the extreme value of $1 / \phi=8$ was calculated (Dubinsky et al. 1984a). One would expect quantum yields to increase with depth in water column profiles, reaching a maximal value under dim light. This trend does not occur in turbulent and mixed waters as all cells are acclimated to some average light intensity. However, in stable, stratified water bodies, there may be an increase in quantum yield until peak value is reached, as cells have time to become acclimated to decreasing light (Dubinsky \& Berman 1976, Dubinsky et al. 1984a). The depth related increases are due to the fact that at first pigment increase leads to a higher fraction of impinging light being harvested. As light further decreases, that effect becomes self-limiting, thereby reducing the efficiency of $\mathrm{a}^{*}$ and of any further incremental pigmentation. For definitions and discussion of the ecological versus biophysical quantum yields of aquatic photosynthesis see Dubinsky (1980) and Schanz et al. (1997).

\section{LIGHT-SATURATED RATE OF PHOTOSYNTHESIS, $P_{\max }$}

The light-saturated rate of photosynthesis, $P_{\max }$ is strongly affected by photoacclimation and may easily be 5-fold lower in lowlight-acclimated cultures than in their highlight counterparts (Fig. 7D). This difference was found to closely correlate with the amount of RUBISCO per PSU (Fisher et al. 1989, 1996). Operationally, the amount of RUBISCO limits the electronrate throughput between the 2 photosystems, thus increasing $\tau$ values, or the full turnover time required for 'trap reopening' following its photon capture driven 
reduction. Values of $\tau$ can range between $15 \mathrm{~ms}$ in lowlight-grown cells to $1.5 \mathrm{~ms}$ in highlight ones (Fig. 7E). Even though the bottleneck might be elsewhere in the electron transport and utilization chain, in acclimated cells the capacity for photosynthesis will be matched, if not determined by RUBISCO. The relation of cellular RUBISCO content and its ratio to PSU numbers is functionally understandable as a way to maximize electron flow under high light, thereby conferring protection from free-radical photodynamic damage, while avoiding the costly investment in the biosynthesis of unneeded RUBISCO under low light.

In addition to the rate of light absorption, $P_{\max }$ per cell is limited by other factors, most strongly by temperature, since all biochemical reactions proceed faster at higher temperature up to the limit set by the thermal stability of proteins (e.g. Falkowski \& Raven 2007, Baumert \& Petzoldt 2008).

\section{THERMAL ENERGY DISSIPATION, NPQ AND THE XANTHOPHYLL CYCLE}

While non-cyclic photophosphorylation under the ' $\mathrm{Z}$ scheme' requires 1:1 PSI/PSII electron excitation, the concomitant electron flow through cyclic photophosphorylation only involves the faster PSI activity. Thus, it is possible to have different PSI/PSII ratios, which increase under high irradiance providing ATP for rapid cell synthesis and damage repair (Herzig \& Dubinsky 1993).

Vital excess-energy dissipation by means of thermal loss takes place directly following the absorption of light by pigments, typically amounting to well over $50 \%$ of the total light harvested (Cha \& Mauzerall 1992). NPQ is commonly estimated from quenching of fluorescence, attributable to losses other than storage through photochemistry. A novel and most effective tool to directly study thermal dissipation became available with the advent of the application of photoacoustics to the study of phytoplankton photosynthesis (Dubinsky et al. 1998, Pinchasov et al. 2007). This method can verify and complement the proxy estimation of thermal dissipation emerging as NPQ, derived from the different variable fluorescence methods and instruments (e.g. Kolber et al. 1998). One should note that the estimates of oxygenic photosynthesis based on pulse-amplitude-modulated (PAM) and fast-repetition-rate (FRR) fluorometers are influenced by species and photoacclimation state (Johnsen \& Sakshaug 2007 , Suggett et al. 2009). The thermal dissipation process is assisted and enhanced by the nearly universal function of the xanthophyll cycle (Demmig-Adams \& Adams 1996). The pigments involved differ among taxa, with zeaxanthin, violaxanthin, and antheraxanthin in plants and chlorophytes replaced by diadinoxanthin and dinoxanthin in other algae. Under highlight, a larger amount of the cycle constituents are formed and, upon exposure to light, they undergo epoxidation. In this state, they shunt light energy from photochemistry towards thermal dissipation, decaying as light intensity decreases to the state where light energy is predominantly directed to the photosynthetic machinery.

\section{CORAL-ZOOXANTHELLAE PHOTOACCLIMATION}

Corals, widespread marine coelenterates harboring microalgal symbionts (zooxanthellae) in their cells as 'captive phytoplankton,' offer a perfect in situ experimental system to study photoacclimation. Indeed, they show 5-fold variation in areal chlorophyll and corresponding absorptivity between the extremes of their light intensity-related bathymetric distribution. In zooxanthellae, quantum yields also show a dramatic span from the theoretically maximal $\phi=1 / 8$ under $0.5 \%$ of subsurface light to values $<0.01$ of those at the intensely illuminated reef table (e.g. Stambler \& Dubinsky 2004, Levy et al. 2006, Stambler et al. 2008).

\section{PHOTOACCLIMATION IN THE ECOSYSTEM}

The finely coordinated mechanisms of photoacclimation allow aquatic phytoplankters to survive over a 2 order of magnitude range of ambient irradiance. However, it is noteworthy that photoacclimation to low light requires adequate nutrient supply (Herzig \& Falkowski 1989, Berges et al. 1996, Cardol et al. 2008), and in many cases, cells that successfully acclimate to high light have difficulties in obtaining sufficient nutrients to maintain Redfield ratios to keep up with the fast carbon influx (Berman-Frank \& Dubinsky 1999). Conversely, in poorly buffered freshwaters, it is common that $\mathrm{CO}_{2}$ availability prevents cells from fully benefitting from photoacclimation, as RUBISCO may become counterproductive, switching to its oxygenase role (Raven 1991, Spijkerman 2008). Thus, by efficiently harvesting any available glimmer of light and avoiding highlight damage, they still pay tax in terms of reduced growth whenever light is limiting.

In the Gulf of Eilat during stratification, where the thermocline is at 60 to $80 \mathrm{~m}\left(z_{\text {mix }}\right)$ and the depth at which light is reduced to $1 \%$ of it subsurface intensity $\left(z_{1 \%}\right)$ extends all the way to $90-115 \mathrm{~m}$, and the water column is stable, there is sufficient time for picophytoplankton cells to photoacclimate. This is evident in the increase of chlorophyll per cell with depth. The converse is true during the mixing period (winter time) when the mixing depth $z_{\text {mix }}$ can reach $600 \mathrm{~m}$, far 
beyond the $z_{1} \%$ depth, which at that time is about $80 \mathrm{~m}$, and the cells do not show photoacclimation (Stambler 2006). In general if $z_{\text {mix }}>z_{1} \%$, acclimation is rather uniform over depth, provided that the time required for mixing (that is, travel of an algal cell through the light gradient within the mixed layer) is shorter than the time required for acclimation. If $z_{\text {mix }}<z_{1} \%$, acclimation of shallow water phytoplankton cells differs from that of deep ones (Falkowski \& Wirick 1981). In Lake Kinneret, $z_{1} \%$ ranges between a maximum of $15.17 \mathrm{~m}$ and a minimum of $1.86 \mathrm{~m}$, depending on the vernal bloom of the dinoflagellate Peridinium gatunense (Yacobi 2006). During summertime stratification, the $z_{1} \%$ depth is far shallower than the thermocline, which is usually located at $15 \mathrm{~m}$ (Yacobi 2006), whereas following the autumnal overturn and mixing to the lake bottom, $z_{\text {mix }}$ $>z_{1} \%$. Thus, during stratification, cellular chlorophyll increases with depth (Yacobi 2003, Walsby et al. 2003, Z. Dubinsky pers. comm.). Concomitantly, there is a reverse trend of increase in cellular concentration of $\beta$-carotene and diadinoxanthin, parallel to that of impinging photon flux, indicating a rise in the photoprotective capability of highlight-acclimated Peridinium cells. It seems that photoacclimation in Peridinium is not achieved via change in the size of the photosynthetic units (Yacobi 2003).

On the population level, photoadaptation of photosynthesis to the optical marine environment and the bathymetric separation of different taxa and strains is the next step beyond photoacclimation. The terms photoacclimation and photoadaptation have been used in many cases as synonyms; however, more recently, acclimation is reserved for phenotypic changes taking place in response to environmental cues during the lifetime of the cell, while adaptation is usually (not exclusively) used for genomic changes occurring in a population on an evolutionary time scale (for formal definitions see Table 1). For instance, based on lightdependent physiology and molecular phylogeny, 2 ecotypes of Prochlorococcus characterized: a highlight-adapted ecotype, characterized by relatively low chl $b / c h l$ a ratios, and a lowlight-adapted ecotype, with high chl b/chl a ratios (Moore \& Chisholm 1999). In the case of the green, picoeukaryote Ostreococcus, the variation between the low/high light strains is amplified by high nutrient and Fe concentrations in the environment (Cardol et al. 2008).

The effect of photoacclimation on seasonal phytoplankton dynamics has to be viewed in relation to the critical depth (Kirk 1994), as it allows growth of cells at greater depth than would have been otherwise possible. Photoacclimation allows photosynthetic gains to surpass respiratory losses further down the water column than would be possible without photoacclimation, thereby pushing the euphotic depth deeper and increasing the duration of time allowing cell multiplication, as long as $z_{\text {eu }}>$ mixing depth. An example is the case of Aphanizomenon ovalisporum in Lake Kinneret, where from mid-March to late October, $z_{\mathrm{eu}}$ exceeds the mixed depth, leading to proliferation of this potentially toxic organism in Israel's main drinking water source (Porat et al. 2000, Walsby et al. 2003).

\section{SUMMARY}

In general, whenever exposed to a change in irradiance in a spatially and temporally dynamic light field, phytoplankton have developed an array of interrelated cellular mechanisms allowing them to optimize light harvesting and utilization. These responses form the phenotypic process termed photoacclimation, which includes adjustment of optical properties involved in the 'light reactions' of photosynthesis, fine tuning RUBISCO levels to optimize electron throughput in the 'dark reactions' and providing optical and enzymatic safeguards against highlight damage. The outcome of the photoacclimation process mitigates extreme light intensity fluctuations, reducing their effect to levels allowing growth beyond mere survival. Phototrophs trapped in permanent light domains, such as zooxanthellae, symbionts 'captive' within coral cells, Prochloron in didemnid ascidians (Munchhoff et al. 2007), algae within mat layers or in soil, have been selected over evolutionary time scales for their ability to cope with the light in their niches, resulting in 'photoadapted' genotypes.

Understanding the processes and limitations of photoacclimation is crucial in the design of production scale algal mass cultures, whether in open ponds (Borowitzka 1995, 2005) or in photobioreactors (Dubinsky et al. 1995). Photoacclimation affects concentrations and yields of valuable products such as carotenoids, polyunsaturated fatty acids, polysaccharides and highly fluorescent phycobilins (Martinez \& Dubinsky 2004). Therefore, the properties of light fields in commercial algal mass cultures should be key considerations in their design and operational parameters (Dubinsky et al. 1995). Eventually, the economics of such currently en vogue ventures like production of biodiesel from algal cultures, necessitates an elementary understanding of photoacclimation and its effect on ceilings imposed by quantum yields and profits per unit area.

\section{LITERATURE CITED}

Anwaruzzaman M, Chin BL, Li XP, Lohr M, Martinez DA, Niyogi KK (2004) Genomic analysis of mutants affecting xanthophyll biosynthesis and regulation of photosynthetic 
light harvesting in Chlamydomonas reinhardtii. Photosynth Res 82:265-276

Arteni AA, Liu LN, Aartsma TJ, Zhang YZ, Zhou BC, Boekema EJ (2008) Structure and organization of phycobilisomes on membranes of the red alga Porphyridium cruentum. Photosynth Res 95:169-174

Banse K (2004) Should we continue to use the 1-\% light depth convention for estimating the compensation depth of phytoplankton for another 70 years? Limnol Oceanogr Bull 13:49-52

Baumert HZ, Petzoldt T (2008) The role of temperature, cellular quota and nutrient concentrations for photosynthesis, growth and light-dark acclimation in phytoplankton. Limnologica 38:313-326

Berges JA, Charlebois DO, Mauzerall DC, Falkowski PG (1996) Differential effects of nitrogen limitation on photosynthetic efficiency of photosystems I and II in microalgae. Plant Physiol 110:689-696

Berman-Frank I, Dubinsky Z (1999) Balanced growth in aquatic plants: myth or reality? Phytoplankton use the imbalance between carbon assimilation and biomass production to their strategic advantage. Bioscience 49:29-37

Berner T, Wyman K, Dubinsky Z, Falkowski PG (1989) Photoadaptation and the 'packace' effect in Dunaliella tertiolecta (Chlorophyceae). J Phycol 25:70-78

Bidigare RR, Marra J, Dickey TD, Iturriaga R, Baker KS, Smith RC, Pak H (1990) Evidence for phytoplankton succession and chromatic adaptation in the Sargasso Sea during spring 1985. Mar Ecol Prog Ser 60:113-122

- Bidigare RR, Ondrusek ME, Kennicutt MC, Iturriaga R, Harvey HR, Hoham RW, Macko SA (1993) Evidence for a photoprotective function for secondary carotenoids of snow algae. J Phycol 29:427-434

Borowitzka MA (1995) Microalgae as sources of pharmaceuticals and other biologically-active compounds. J Appl Phycol 7:3-15

Borowitzka MA (2005) Cultivation of microalgae from village level to industrial scale. Phycologia 44:11-12

> Boussiba S, Vonshak A (2000) Carotenogenesis in the green alga Haematococcus pluvialis: cellular physiology and stress response. Physiol Plant 108:111-117

Boussiba S, Bing W, Yuan JP, Zarka A, Chen F (1999) Changes in pigments profile in the green alga Haeamtococcus pluvialis exposed to environmental stresses. Biotechnol Lett 21:601-604

- Cardol P, Bailleul B, Rappaport F, Derelle E and others (2008) An original adaptation of photosynthesis in the marine green alga Ostreococcus. Proc Natl Acad Sci USA 105:7881-7886

Cha Y, Mauzerall DC (1992) Energy-storage of linear and cyclic electron flows in photosynthesis. Plant Physiol 100: 1869-1877

Choudhury NK, Behera RK (2001) Photoinhibition of photosynthesis: role of carotenoids in photoprotection of chloroplast constituents. Photosynthetica 39:481-488

Cullen JJ, Lewis MR (1988) The kinetics of algal photoadaptation in the context of vertical mixing. J Plankton Res 10: 1039-1063

Cullen JJ, MacIntyre JG (1998) Behavior, physiology and the niche of depth-regulating phytoplankton. In: Anderson DM Cemballa AD, Hallegraeff GM (eds) Physiological ecology of harmful algal blooms. Springer-Verlag, Heidelburg, p 559-580

Cunningham FX, Dennenberg RJ, Mustardy L, Jursinic PA, Gantt E (1989) Stoichiometry of photosystem-I, photosystem-II, and phycobilisomes in the red alga Porphyridiumcruentum as a function of growth irradiance. Plant Physiol 91:1179-1187
Demers S, Roy S, Gagnon R, Vignault C (1991) Rapid lightinduced changes in cell fluorescence and in xanthophyllcycle pigments of Alexandrium excavatum (Dinophyceae) and Thalassiosira pseudonana (Bacillariophyceae): a photoprotection mechanism. Mar Ecol Prog Ser 76:185-193

> Demmig-Adams B, Adams WW (1996) The role of xanthophyll cycle carotenoids in the protection of photosynthesis. Trends Plant Sci 1:21-26

Dring MJ (1981) Chromatic adaptation of photosynthesis in benthic marine-algae - an examination of its ecological significance using a theoretical-model. Limnol Oceanogr 26:271-284

Dubinsky Z (1980) Light utilization efficiency in natural phytoplankton communities. In: Falkowski PG (ed) Primary productivity in the sea. Plenum, New York, p 83-97

Dubinsky Z, Berman T (1976) Light utilization efficiencies of phytoplankton in Lake Kinneret (Sea of Galilee). Limnol Oceanogr 21:226-230

Dubinsky Z, Berman T (1979) Seasonal changes in the spectral composition of downwelling irradiance in lake Kinneret (Israel). Limnol Oceanogr 24:652-663

Dubinsky Z, Berman T (1981) Light utilization by phytoplankton in Lake Kinneret (Israel). Limnol Oceanogr 26:660-670

Dubinsky Z, Schofield O (in press) The light from the darkness: thriving at the light extremes in nature. Hydrobiology

> Dubinsky Z, Berman T, Schanz F (1984a) Field experiments for in situ measurement of photosynthetic efficiency and quantum yield. J Plankton Res 6:339-349

> Dubinsky Z, Falkowski PG, Porter JW, Muscatine L (1984b) Absorption and utilization of radiant energy by light- and shade-adapted colonies of the hermatypic coral Stylophora pistillata. Proc R Soc Lond B 222:203-214

Dubinsky Z, Falkowski PG, Wyman K (1986) Light harvesting and utilization in phytoplankton. Plant Cell Physiol 27: $1335-1350$

Dubinsky Z, Matsukawa R, Karube I (1995) Photobiological aspects of algal mass culture. J Mar Biotechnol 2:61-65

Dubinsky Z, Feitelson J, Mauzerall DC (1998) Listening to phytoplankton: measuring biomass and photosynthesis by photoacoustics. J Phycol 34:888-892

Dufosse L, Galaup P, Yaron A, Arad SM (2005) Microorganisms and microalgae as sources of pigments for food use: a scientific oddity or an industrial reality? Trends Food Sci Technol 16:389-406

Emerson R, Arnold W (1932) The photochemical reaction in photosynthesis. J Gen Physiol 16:191-205

Falkowski PG, La Roche J (1991) Acclimation to spectral irradiance in algae. J Phycol 27:8-14

Falkowski PG, Raven JA (2007) Aquatic photosynthesis. Princeton University Press, Princeton, NJ

Falkowski PG, Wirick CD (1981) A simulation model of the effects of vertical mixing on primary productivity. Mar Biol 65:69-75

Falkowski PG, Dubinsky Z, Wyman K (1985) Growth-irradiance relationships in phytoplankton. Limnol Oceanogr 30: 311-321

Fan L, Vonshak A, Rachel G, Hirshberg J, Cohen Z, Boussiba $S$ (1995) The biosynthetic pathway of astaxanthin in a green alga Haematococcus pluvialis as indicated by inhibition with diphenylamine. Plant Cell Physiol 36: 1519-1524

Fisher T, Schurtz-Swirski R, Gepstein S, Dubinsky Z (1989) Changes in the levels of ribulose-1,5-bisphosphate carboxylase/oxygenase (RUBISCO) in Tetraedron minimum (Chlorophyta) during light and shade adaptation. Plant Cell Physiol 30:221-228 
Fisher T, Minnaard J, Dubinsky Z (1996) Photoacclimation in the marine alga Nannochloropsis sp. (Eustigmatophyte): a kinetic study. J Plankton Res 18:1797-1818

Fisher T, Berner T, Iluz D, Dubinsky Z (1998) The kinetics of the photoacclimation response of Nannochloropsis sp. (Eustigmatophyceae): a study of changes in ultrastructure and PSU density. J Phycol 34:818-824

Geider RJ, Platt T, Raven JA (1986) Size dependence of growth and photosynthesis in diatoms: a synthesis. Mar Ecol Prog Ser 30:93-104

Gloag RS, Ritchie RJ, Chen M, Larkum AWD, Quinnell RG (2007) Chromatic photoacclimation, photosynthetic electron transport and oxygen evolution in the chlorophyll $d$ containing oxyphotobacterium Acaryochloris marina. Biochim. Biochim Biophys Acta Bioenerg 1767:127-135

Herzig R, Dubinsky Z (1992) Photoacclimation, photosynthesis, and growth in phytoplankton. Isr J Bot 41:199-212

Herzig R, Dubinsky Z (1993) Effect of photoacclimation on the energy partitioning between cyclic and noncyclic photophosphorylation. New Phytol 123:665-672

Herzig R, Falkowski PG (1989) Nitrogen limitation in Isochrysis galbana (Haptophyceae). 1. Photosynthetic energyconversion and growth efficiencies. J Phycol 25:462-471

Jeffrey SW, Humphrey GF (1975) New spectrophotometric equations for determining chlorophylls $\mathrm{a}, \mathrm{b}, \mathrm{c}_{1}$ and $\mathrm{c}_{2} \mathrm{n}$ higher plants, algae and natural phytoplankton. Biochem Physiol Pflanz 167:191-194

Jerlov NG (1976) Elsevier oceanography series, 14. Marine optics. Elsevier Scientific, Amsterdam

> Johnsen G, Sakshaug E (2007) Biooptical characteristics of PSII and PSI in 33 species (13 pigment groups) of marine phytoplankton, and the relevance for pulse-amplitudemodulated and fast-repetition-rate fluorometry. J Phycol 43:1236-1251

Kehoe DM, Gutu A (2006) Responding to color: the regulation of complementary chromatic adaptation. Annu Rev Plant Biol 57:127-150

Kirk JTO (1986) Optical properties of picoplankton suspensions. Can Bull Fish Aquat Sci 214:501-520

Kirk JTO (1994) Light and photosynthesis in aquatic ecosystems. 2nd edn. Cambridge University Press, London

Kolber ZS, Prasil O, Falkowski PG (1998) Measurements of variable chlorophyll fluorescence using fast repetition rate techniques: defining methodology and experimental protocols. Biochim Biophys Acta Bioenerg 1367:88-106

Krinsky NI (1989) Antioxidant functions of carotenoids. Free Radic Biol Med 7:617-635

Kromkamp JC, Domin A, Dubinsky Z, Lehmann C, Schanz F (2001) Changes in photosynthetic properties measured by oxygen evolution and variable chlorophyll fluorescence in a simulated entrainment experiment with the cyanobacterium Planktothrix rubescens. Aquat Sci 63:363-382

- Latowski D, Grzyb J, Strzalka K (2004) The xanthophyll cycle-molecular mechanism and physiological significance. Acta Physiol Plant 26:197-212

Levy O, Achituv Y, Yacobi YZ, Dubinsky Z, Stambler N (2006) Diel 'tuning' of coral metabolism: physiological responses to light cues. J Exp Biol 209:273-283

Lobban CS, Harrison PJ (1996) Seaweeds ecology and physiology. Cambridge University Press, Cambridge

MacIntyre HL, Kana TM, Anning T, Geider RJ (2002) Photoacclimation of photosynthesis irradiance response curves and photosynthetic pigments in microalgae and cyanobacteria. J Phycol 38:17-38

Marra J, Trees CC, O'Reilly JE (2007) Phytoplankton pigment absorption: a strong predictor of primary productivity in the surface ocean. Deep-Sea Res I 54:155-163
Martinez R, Dubinsky Z (2004) Useful products from aquatic photosynthesis. In: Archer M, Barber J (eds) Photoconversion of solar energy, Vol 2. Molecular to global photosynthesis. Imperial College Press, London

Moisan TA, Ellisman MH, Buitenhuys CW, Sosinsky GE (2006) Differences in chloroplast ultrastructure of Phaeocystis antarctica in low and high light. Mar Biol 149: $1281-1290$

Moore LR, Chisholm SW (1999) Photophysiology of the marine cyanobacterium Prochlorococcus: ecotypic differences among cultured isolates. Limnol Oceanogr 44: 628-638

Munchhoff J, Hirose E, Maruyama T, Sunairi M, Burns BP, Neilan BA (2007) Host specificity and phylogeography of the prochlorophyte Prochloron sp., an obligate symbiont in didemnid ascidians. Environ Microbiol 9:890-899

Oberhaus L, Briand JF, Leboulanger C, Jacquet S, Humbert JF (2007) Comparative effects of the quality and quantity of light and temperature on the growth of Planktothrix agardhii and P. rubescens. J Phycol 43:1191-1199

Palenik B (2001) Chromatic adaptation in marine Synechococcus strains. Appl Environ Microbiol 67:991-994

> Pinchasov Y, Porat R, Zur B, Dubinsky Z (2007) Photoacoustics: a novel tool for the determination of photosynthetic energy storage efficiency in phytoplankton. Hydrobiologia 579:251-256

Porat R, Teltsch B, Dubinsky Z, Walsby AE (2000) Effects of light and pressure on gas vesicle formation and buoyancy in Aphanizomenon ovalisporum Forti (Cyanobacteria) from Lake Kinneret, Israel. Ergeb Limnol 55: 333-348

> Post AF, Dubinsky Z, Wyman K, Falkowski PG (1984) Kinetics of light intensity adaptation in a marine plankton diatom. Mar Biol 83:231-238

Prézelin BB (1981) Light reactions in photosynthesis. Can Bull Fish Aquat Sci 210:1-43

> Prézelin BB, Tilzer MM, Schofield O, Haese C (1991) The control of the production process by the physical structure of the aquatic environment with special reference to its optical properties. Aquat Sci 53:136-186

Raps S, Wyman K, Siegelman HW, Falkowski PG (1983) Adaptation of the cyanobacterium Microcystis aeruginosa to light intensity. Plant Physiol 72:829-832

Raven JA (1991) Physiology of inorganic C acquisition and implication for resource use efficiency by marine phytoplankton: relation to increased $\mathrm{CO}_{2}$ and temperature. Plant Cell Environ 14:779-794

> Rech M, Morant-Manceau A, Tremblin G (2008) Carbon fixation and carbonic anhydrase activity in Haslea ostrearia (Bacillariophyceae) in relation to growth irradiance. Photosynthetica 46:56-62

> Rimmer A, Ostrovsky I, Yacobi YZ (2008) Light availability for Chlorobium phaeobacteroides development in Lake Kinneret. J Plankton Res 30:765-776

Schagerl M, Muller B (2006) Acclimation of chlorophyll $a$ and carotenoid levels to different irradiances in 4 freshwater cyanobacteria. J Plant Physiol 163:709-716

Schanz F, Senn P, Dubinsky Z (1997) Light absorption by phytoplankton and the vertical light attenuation: ecological and physiological significance. Oceanogr Mar Biol Annu Rev 35:71-95

Smith RC, Mobley CD (2008) Underwater light. In: Björn LO (ed) Photobiology: the science of life and light, 2nd edn. Springer, New York, p 131-138

Spijkerman E (2008) What physiological acclimation supports increased growth at high $\mathrm{CO}_{2}$ conditions? Physiol Plant 133:41-48 
Stambler N (2006) Light and picophytoplankton in the Gulf of Eilat (Aqaba) J Geophys Res 111:C11009, doi:10.1029/ 2005JC003373

Stambler N, Dubinsky Z (2004) Stress effects on metabolism and photosynthesis of hermatypic corals. In: Rosenberg E, Loya Y (eds) Coral health and disease. Springer-Verlag, Berlin, p 195-215

Stambler N, Dubinsky Z (2007) Marine phototrophs in the twilight zone In: Seckbach J (ed) Algae and cyanobacteria in extreme environments series: cellular origin, life in extreme habitats and astrobiology, Vol 11. Springer, Dordrecht, p 79-97

Stambler N, Levy O, Vaki L (2008) Physiological response of hermatypic Red Sea corals at distribution depth of 5-75 m. Isr J Plant Sci 56:45-53

Subramaniam A, Carpenter EJ, Karentz D, Falkowski PG (1999) Bio-optical properties of the marine diazothrophic cyanobacteria Trichodesmuim spp. I. Absorption and photosynthetic action spectra. Limnol Oceanogr 44: 608-617

Suggett DJ, Le Floc'H E, Harris GN, Leonardos N, Geider RJ (2007) Different strategies of photoacclimation by 2 strains of Emiliania huxleyi (Haptophyta). J Phycol 43:1209-1222

Suggett DJ, Moore CM, Hickman AE, Geider RJ (2009) Interpretation of fast repetition rate (FRR) fluorescence: signatures of phytoplankton community structure versus physiological state. Mar Ecol Prog Ser 376:1-19

Talarico L, Maranzana G (2000) Light and adaptive responses in red macroalgae: an overview. J Photochem Photobiol B Biol 56:1-11

Talling JF (1957) Photosynthetic characteristics of some fresh-

Editorial responsibility: Tom Berman,

Migdal, Israel water plankton diatoms in relation to underwater radiation. New Phytol 56:29-50

Walsby AE, Dubinsky Z, Kromkamp JC, Lehmann C, Schanz $F$ (2001) The effects of diel changes in photosynthetic coefficients and depth of Planktothrix rubescens on the daily integral of photosynthesis in Lake Zürich. Aquat Sci 63:326-349

Walsby AE, Yacobi YZ, Zohary T (2003) Annual changes in the mixed depth and critical depth for photosynthesis by Aphanizomenon ovalisporum that allow growth of the cyanobacterium in Lake Kinneret, Israel. J Plankton Res 25:603-619

Wang B, Zarka A, Trebst A, Boussiba S (2003) Astaxanthin accumulation in Haematococcus pluvialis (Chlorophyceae) as an active photoprotective process under high irradiance. J Phycol 39:1116-1124

Wolfe-Simon FD, Grzebyk D, Schofield O, Falkowski PG (2005) The role and evolution of superdioxide dismutases in algae. J Phycol 41:453-465

- Yacobi YZ (2003) Seasonal variation in pigmentation of the dinoflagellate Peridinium gatunense (Dinophyceae) in Lake Kinneret, Israel. Freshw Biol 48:1850-1858

Yacobi YZ (2006) Temporal and vertical variation of chlorophyll alpha concentration, phytoplankton photosynthetic activity and light attenuation in Lake Kinneret: possibilities and limitations for simulation by remote sensing. J Plant Res 28:725-736

Zlotnik I, Sukenik A, Dubinsky Z (1993) Physiological and photosynthetic changes during the formation of red aplanospores in the chlorophyte Haematococcus pluvialis. J Phycol 29:463-469

Submitted: August 5, 2008; Accepted: July 2, 2009

Proofs received from author(s): August 16, 2009 